\title{
Impact of Brand Image on the Profitability of Firm, Analysis of Nestle Company Pakistan
}

Shamim Akhtar*, Zhao Xicang and Shuja Iqbal

School of Management, Jiangsu University, Zhenjiang, P. R. China

\begin{abstract}
Introduction: The purpose of this study is to determine the impact of brand image on the firm's profit. There are different dimensions of brand image that can affect the ultimate customers to have them. Some of the traits can be categorized here are quality of a specific product, product name, packaging and slogan etc. Different dimensions of brand image are discussed for an in depth analysis. These include "brand packaging", "brand personality" and "word of mouth". Hence after applying the particular tests the ultimate effect of all these aspects are checked on the profitability of Nestle Company on the basis of the data collected.
\end{abstract}

Methodology applied: A questionnaire method is used to collect the data about the awareness of the brand. Probability sampling is used for this purpose, as the products Nestle Company are being consumed by almost all types of age of people.

Findings and results: The results are obtained through applying tests include Correlation and Regression analysis. The outcomes are; the brand personality has positive impact on word of mouth and profitability with moderate strength, whereas brand packaging showed also positive impact, but the relation is weak. Word of mouth on other side revealed positive relation with profitability with good strength.

Originality of the study: This study focused on the aspect to earn the profit through intangible asset that is brand image. This will help the owners and the managers of a Company to attain maximum benefits by the implication of these results. The results of this research will help firms to focus on brand image for better profits.

Keywords: Impact; Brand image; Profitability; Firm; Nestle; Brand

\section{Introduction}

Branding is a process which creates a unique name and image for a product in the minds of consumers. This mainly uses the advertising campaigns designed by the companies to promote its products. Branding plays an important role increasing brand equity (brand equity means the power of a brand which it attains from the goodwill and by the recognition of its name, which in turn increases the sales volume and profit) and the brand loyalty (brand loyalty means the commitment of a consumer to repurchase a product). Brand image (describes the consumer's belief and thoughts towards a specific product) enhances the consumer's trust and enables the company to differentiate its services from other enterprises in the industry and also to satisfy the consumers [1]. Positive brand image attracts the clients and build associations which ultimately cultivate better profits. Branding differentiates the products of companies.

\section{Literature Review}

The differentiation of a product/service from others is now a crucial need for survival in severe competition. Therefore, knowing the importance of branding, from the previous ten years there is a typical increase in the research interest of brands where customer feel good for highly preferred brands. Accepting the relationships between consumers and their brands has realistic significance to marketers because it has noteworthy effect on the profit/revenues of company [2].

As in the international market now- a-days brand management concept is reached to a new point. Marketers have creative skills to develop brands and ultimately mange them. This works in the higher education also in colleges and universities which today focus on branding for their reputation and to attract the new customers as well [3].

Mostly it happens that companies with inferior brand image tend to acquire the firm having strong brand image, to improve its own brand in order to cultivate higher profit margins by cutting cost with a focus on the financial performance. Hence a strong brand name contributes a lot towards reputation and as well as income of the firm [4]. The case is that branding is not only a marketing strategy for particular issue, but it openly affects the profitability of firm. The economic contribution of brand image and brand equity is a base to manage the branding portfolios (separate business units). At the first stage product should set free to be accepted by the customers then after that brand should allow excelling its force. This needs obviously a huge investment on initial stages. Brand presents the company to breed maximum margins in future cash flows. In a study conducted for a museum, to check the brand orientation, signaled that for the survival of museum, brand management is the need of the hour.

This was described that competitive advantages are followed by the strong brand names of the firm. This amplifies organization's cash inflows and pick up the pace for the liquidity, provide a way to charge higher prices, profitability and provide repeat purchases by the consumers. The brand image also makes feasible for the company to diversify its products or extend its brands. Hence creates positive image in the minds of the customers, which reflects the awareness about the brand which in turn is necessary for the efficient management of

*Corresponding author: Shamim Akhtar, School of Management, Jiangsu University, Zhenjiang, P.R. China, Tel: + +8618605240210; E-mail: Shamim. akhtar37@hotmail.com

Received November 01, 2017; Accepted November 22, 2017; Published November 30, 2017

Citation: Akhtar S, Xicang Z, Iqbal S (2017) Impact of Brand Image on the Profitability of Firm, Analysis of Nestle Company Pakistan. Review Pub Administration Manag 5: 230. doi:10.4172/2315-7844.1000230

Copyright: (C) 2017 Akhtar S, et al. This is an open-access article distributed under the terms of the Creative Commons Attribution License, which permits unrestricted use, distribution, and reproduction in any medium, provided the original author and source are credited. 
branding. Brand image increases the brand equity which lower down production costs, cultivate more profit. When customers become more loyal to a specific brand then firms try to find out the more distribution channels, better communications spots, which provide ease to develop a new brand and sell it in the market [5].

As study reveals that after the extension of a particular brand, beside parent brand only the product brand image is considered by the consumers However sometimes customers become overlap with the development of new brand and disturbs the company's profit margins. For this reason, firms should take great care in the development and extending a new brand in the market. Here matter three significant factors that are, favorability, strength and uniqueness of brand [6]. If the customers' mind has favorable attitude towards a brand, then brand message will affect intensely rather than competitors. Consequently, brand image is a vital determinant of a buyer's activities. Observing the packaging of a product is attaining more weight to sell a product, a study is developed on Patterzon Zoconist Cussons in Nigeria found that packaging is important when companies consider their processes of branding. As it directly or indirectly plays a key role for communicating the image and identity of the organization. Hence the result found by the study determined that $98 \%$ of the variance is occurred due to the packaging and also other aspects like brand name, price etc. Packaging may be affected by a better box to cover, a new style of a bottle or a can may even give strong reputation for unknown company with already strong competitors, which results in higher turnover of sales [7].

As on one side there is the growing and enormous importance of the packaging, on the other side some users of the products also complain about it. Some critics in the business argue that the designs of the packaging, its labeled wording, colors and verity of other aspects, sometimes give the wrong impression about the product to the customer. This in result creates the difficulty to make a comparison among products provided at one place. So, their buying decisions may change which will ultimately affect the sales [8]. The experimental data and numerical results have shown that in the sports wear industry alone brand image along with high perceived quality is not a guarantee of the success in the market.

The comparison of a product in packaging can be further detailed among the type of consumers. For example, different age of consumers demands different styles of packaging. Hence when we consider the choice of children products then there is the need to focus two clients, first the parents who shop the products for their children and the second children who actually use that product. Therefore, having the wrong decision at this point will certainly kill the brand (About us: ehow). And it is also observed that maximum users judge the product by the packaging style.

Companies need to communicate their information to its consumers about their products. Along with selecting appropriate advertising campaigns, the selection of favorite celebrity to promote a brand is also necessary especially when it is selected on the demand of customers.

Selecting brand personality means hiring a celebrity/famous person for a brand and spread communication to the consumers through his/her message, which can influence the users to purchase that product especially when there is the involvement of fashion, style integrity and love.

One of the functions that a specific brand performs is the relational function which contributes that a brand personality makes it possible to form a relation with the customers [2]. Brand personality traits provide symbolic meaning or emotional value that can contribute to increase consumers' brand preferences. Successfully positioning is required basically.

Positive brand image creates a positive effect on the customer's action to buy a product by boosting loyalty, chance to charge high prices and spreading the positive word of mouth about the image of the firm [9].

Successfully positioned personality traits can change the preferences of customers. Building the brand image in the minds of the customers is necessary. And there is also a need to communicate this knowledge. This process changes between business to customer segment and business to business market. This information is needed when to make a purchase decision in the case of $\mathrm{B} 2 \mathrm{~B}$ market. However, this should also notice that in $\mathrm{B} 2 \mathrm{~B}$ market along with economic, financial and the technological benefits, resellers also notice the timely availability of order and the service support by the consulted company. Here the brand representatives effect a lot in the intention of the reseller purchase, even sometimes can be named as ambassadors of brand. This is also necessary that resellers will further elaborate the brand information to the consumers [10].

Word of Mouth (WOM) is described as, a way in which consumers spread the information about a product/service that can force others to buy or to reject to consume a product. Word of mouth is considered as a multi-dimensional concept which is being explained in 3 ways, "Experiential", "Consequential" and "Intentional" word of mouth. Among these three, experiential word of mouth is more important [2]. Whereas the experiential WOM is the consequence when the consumers consume a particular product or a service and hence in the end either fulfill the expectations or there exists some deviation in their expectations. And consequential is the form of communication in which company provides information to the consumers through the advertisements, whereas intentional WOM is observed when organizations specify the famous personalities for the advertisement of their brands. These variables effect the purchasing decisions [11].

In purchasing a product most of the customers now rely on word of mouth and the observational learning which they get from other customers. As a result, some of the customers change their decisions after getting information by word of mouth while some don't. However, the monetary value of word of mouth has been discussed in very few studies [12]

It is investigated that word of mouth can make rapid response from the customer, rather than the expense made through advertising. About $20 \%$ to $50 \%$ of the decisions of consumers to buy a product are now accelerated by word of mouth. This word of mouth is now spreading through social networks even the customers creates the web pages to admire or penalize brands. And this affects the sales and return on investment [11].

As the word of mouth is spreading more from the digital Medias, therefore today in the world, multinational firms are using digital Medias to distribute the information about the company; its performance, quality, products etc. The firms do that indirectly to improve their brands.

Facebook is now becoming the most important one to make different pages or digital posts instead of printed one. Here the company can communicate thousands of consumers and instantly can have the feedback. However, the risk is also associated by the account hackers or the bad slogans which spread more than the good news affecting 


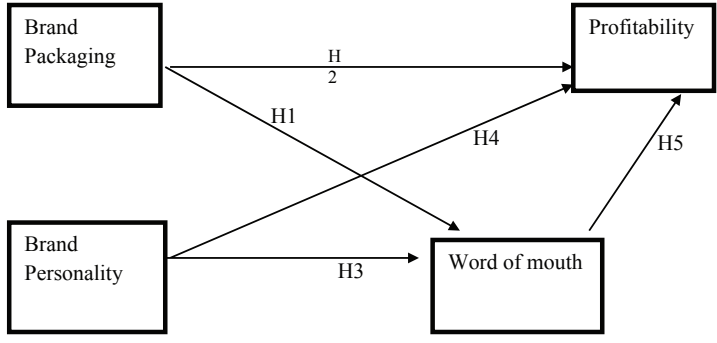

Figure 1: Research model.

\begin{tabular}{|c|c} 
Cronbach's Alpha & N of items \\
\hline 0.874 & 15
\end{tabular}

Table 1: Value of Cronbach's alpha appendixes (Correlations and Regression). H1-Brand packaging has positive impact on Word of Mouth.

the company's overall image or about some specific brand. Companies should conduct researches to analyze the effect of word of mouth. If company receives any complain from public, it should deeply analyze it and then design new ways to solve the issues, this will give the firm a chance to rebuild its image again [13] (Figure 1).

\section{Research Design}

This research is of qualitative nature in which the results are acquired by administering the questionnaire. This study framed the Nestle Company.

\section{Research Tool}

Questionnaire tool is used to collect the data to expose the effect of the brand image on profit. The items in the questionnaire are selfconstructed. The developed questionnaire confirms the value of Cronbach's alpha as 0.874 which determine that its reliability to support the results (Table 1).

\section{Sampling Technique}

Probability sampling technique is used to collect the data.

\section{Sample Size}

Responses are collected from the people having the knowledge of products, its marketing and have some degree of attitude to prefer the branded products of Nestle. 150 respondents gave the responses on which the tests are applied and find the consequences.

\section{Hypothesis}

H1: Brand packaging has positive impact on word of mouth.

H2: Brand packaging has positive impact on profitability.

H3: Brand personality has positive impact on word of mouth.

H4: Brand personality has positive impact on profitability.

H5: Word of mouth has positive impact on profitability.

\section{Test Applied}

Correlation and regression analysis is applied. This explored the strength of relation between independent and dependent variable in case of correlation analysis. Whereas the regression analysis showed the dependency of one variable on the other in terms of percentage change measured.

\section{Findings and Results (Appendixes)}

The outcomes of the study are revealed by correlation and regression computations. This described that the packaging of a particular brand affects the word of mouth but with very low strength. People prefer that they should consume those products which have nice quality of packaging but few of them tell this to others. In the second hypothesis, on the similar grounds, it is noted that people although want to have nice quality of packaging the product, but they don't want to pay more prices but want sustained prices. However, some of them are ready to pay more in terms of prices if the Nestle Company increase the quality of packaging. Celebrity selected by the Nestle for the promotion of its products influences the customers and it has also positive impact on word of mouth. Majority of people tell other about the selected celebrity of a product. And fourth hypothesis, the personality of brand has positive impact on income generated. Which indicates that that the people purchase those products which are promoted by their loved celebrities, hence provides a way to increase the profitability. And the last fifth hypothesis, conclude that word of mouth has also positive impact on profitability which means people purchase products of Nestle if other consumers after having good experience, tell them. This will obviously increase the demand of products and then the profitability. Therefore, it is concluded about the whole study, that brand image affects the profitability means if there is positive image of the company and its products in the minds of the customers then definitely it will make able the firm to have more profits.

\section{Discussion}

\section{Managerial implications}

The consequences of the research and development side of the companies provide the managers that what should they do. Researches show the preferences of the customers either related to business to business market or business to customer market. Hence this study revealed that brand image in either perspective, directly or indirectly, more or less, early or late whatsoever the case may be, it affects the profitability. Therefore managers, marketing or finance, they should take care of this while designing their products or services to build the reputation of organization.

\section{Conclusion}

This research deals with three most important departments of any particular organization (In present case it is Nestle Company), one is marketing, other is Finance and third one is research and development. All of these three need a harmony to attain better profits. Here the managers should work with their maximum zeal so as they are the key players either to boost or to kill the brand (whatsoever the dimension of brand image is) (Tables 2-11).

\begin{tabular}{|c|c|c|c|}
\hline \multicolumn{2}{|c|}{ Pearson correlation } & $\begin{array}{c}\text { Brand } \\
\text { packaging }\end{array}$ & Word of Mouth \\
\cline { 2 - 4 } & Sig. (2-tailed) & $\mathbf{1}$ & $\mathbf{0 . 2 7 3}^{* *}$ \\
\hline \multirow{2}{*}{$\begin{array}{c}\text { Brand } \\
\text { Packaging }\end{array}$} & N & 150 & 0.001 \\
\cline { 2 - 4 } & Pearson Correlation & $0.273^{* *}$ & 150 \\
\hline \multirow{2}{*}{ Word of Mouth } & Sig. (2-tailed) & 0.001 & 1 \\
\cline { 2 - 4 } & $\mathrm{N}$ & 150 & 150 \\
\hline \multirow{2}{*}{${ }^{* *}$ Correlation is significant at the 0.01 level (2-tailed) } \\
\hline
\end{tabular}

Table 2: $\mathrm{H} 1$ : Brand packaging has positive impact on Word of Mouth. 
Citation: Akhtar S, Xicang Z, Iqbal S (2017) Impact of Brand Image on the Profitability of Firm, Analysis of Nestle Company Pakistan. Review Pub Administration Manag 5: 230. doi:10.4172/2315-7844.1000230

Page 4 of 4

\begin{tabular}{|c|c|c|c|c|c|c|}
\hline & Model & Sum of Squares & df & Mean Square & $\mathbf{F}$ & Sig. \\
\hline & Regression & 7.339 & 1 & 7.339 & \multirow{3}{*}{11.891} & \multirow{3}{*}{$0.001^{b}$} \\
\hline \multirow[t]{2}{*}{1} & Residual & 91.335 & 148 & 0.617 & & \\
\hline & Total & 98.673 & 149 & -- & & \\
\hline
\end{tabular}

Table 3: ANOVA.

\begin{tabular}{|c|c|c|c|}
\hline \multicolumn{2}{|c|}{ Pearson Correlation } & Brand Packaging & Profit \\
\cline { 2 - 4 } & Sig. (2-tailed) & $\mathbf{1}$ & $\mathbf{0 . 3 4 4}$ \\
\hline \multirow{3}{*}{ Br Packaging } & N & -- & 0.000 \\
\cline { 2 - 4 } & Pearson Correlation & 150 & 150 \\
\cline { 2 - 4 } & Sig. (2-tailed) & $0.344^{* *}$ & 1 \\
\hline \multirow{2}{*}{ Pack profit } & N & 0.000 & -- \\
\cline { 2 - 4 } & 150 & 150 \\
\hline \multirow{2}{*}{ ** Correlation is significant at the 0.01 level (2-tailed) } \\
\hline
\end{tabular}

Table 4: H2: Brand packaging has positive impact on profitability.

\begin{tabular}{|c|c|c|c|c|c|c|}
\hline & Model & Sum of Squares & df & Mean Square & $\mathbf{F}$ & Sig. \\
\hline \multirow{3}{*}{1} & Regression & 14.502 & 1 & 14.502 & \multirow{2}{*}{19.812} & \multirow{2}{*}{$0.000^{b}$} \\
\hline & Residual & 108.331 & 148 & 0.732 & & \\
\hline & Total & 122.833 & 149 & \multicolumn{3}{|c|}{--} \\
\hline
\end{tabular}

\section{Table 5: ANOVA}

\begin{tabular}{|c|c|c|c|}
\hline \multicolumn{2}{|c|}{ Pearson Correlation } & Brand Personality & Word of mouth \\
\cline { 2 - 4 } & & $\mathbf{1}$ & $\mathbf{0 . 5 7 9 *}$ \\
\hline \multirow{3}{*}{ Brand personality } & Sig. (2-tailed) & -- & 0.000 \\
\cline { 2 - 4 } & N & 150 & 150 \\
\cline { 2 - 4 } & Pearson Correlation & $0.579^{* *}$ & 1 \\
\hline \multirow{2}{*}{ Word of mouth } & Sig. (2-tailed) & 0.000 & -- \\
\cline { 2 - 4 } & N & 150 & 150 \\
\hline${ }^{* *}$ Correlation is significant at the 0.01 level (2-tailed) \\
\hline
\end{tabular}

Table 6: H3: Brand personality has positive impact on word of mouth.

\begin{tabular}{|c|c|c|c|c|c|c|}
\hline \multicolumn{2}{|r|}{ Model } & Sum of Squares & df & Mean Square & $\mathbf{F}$ & Sig. \\
\hline & Regression & 39.352 & 1 & 39.352 & \multirow{3}{*}{74.686} & \multirow{3}{*}{$0.000^{\mathrm{b}}$} \\
\hline \multirow[t]{2}{*}{1} & Residual & 77.981 & 148 & 0.527 & & \\
\hline & Total & 117.333 & 149 & -- & & \\
\hline
\end{tabular}

Table 7: ANOVAa.

\begin{tabular}{|c|c|c|c|}
\hline \multirow{2}{*}{ Pearson Correlation } & Brand Personality & Profit \\
\cline { 2 - 4 } & Sig. (2-tailed) & $\mathbf{1}$ & $\mathbf{0 . 6 2 3}^{* *}$ \\
\hline \multirow{3}{*}{ Brand Personality } & N & -- & 0.000 \\
\cline { 2 - 4 } & Pearson Correlation & $0.623^{* *}$ & 150 \\
\cline { 2 - 4 } & Sig. (2-tailed) & 0.000 & 1 \\
\hline \multirow{2}{*}{ Profit } & N & 150 & 150 \\
\cline { 2 - 4 } & ${ }^{* *}$ Correlation is significant at the 0.01 level (2-tailed) \\
\hline
\end{tabular}

Table 8: H4: Brand personality has positive impact on profitability.

\begin{tabular}{l|l|c|c|c|c|c|}
\hline \multicolumn{2}{|c|}{ Model } & Sum of Squares & df & Mean Square & F & Sig. \\
\hline \multirow{3}{*}{1} & Regression & 55.073 & 1 & 55.073 & & \\
\cline { 2 - 6 } & Residual & 86.800 & 148 & 0.586 & \multirow{2}{*}{93.903} & \multirow{2}{*}{$0.000^{\mathrm{b}}$} \\
\cline { 2 - 6 } & Total & 141.873 & 149 & -- & & \\
\hline $\begin{array}{l}\text { a. Dependent variable: Profit } \\
\text { b. Predictors: (Constant), Brand personality }\end{array}$ \\
\hline
\end{tabular}

Table 9: ANOVA

\begin{tabular}{|c|c|c|c|}
\hline \multicolumn{2}{|c|}{ Pearson Correlation } & Word of mouth & Profit \\
\cline { 2 - 4 } & Sig. (2-tailed) & $\mathbf{1}$ & $\mathbf{0 . 5 3 7 ^ { * * }}$ \\
\hline \multirow{3}{*}{ Word of Mouth } & N & 150 & 0.000 \\
\cline { 2 - 4 } & Pearson Correlation & $0.537^{* *}$ & 150 \\
\cline { 2 - 4 } & Sig. (2-tailed) & 0.000 & 1 \\
\hline \multirow{2}{*}{ Profit } & N & 150 & -- \\
\hline \multirow{2}{*}{$* *$ Correlation is significant at the 0.01 level (2-tailed) } & 150 \\
\hline
\end{tabular}

Table 10: H5: Word of mouth has positive impact on profitability.

\begin{tabular}{|c|c|c|c|c|c|c|}
\hline \multicolumn{2}{|c|}{ Model } & Sum of Squares & df & Mean Square & F & Sig. \\
\hline \multirow{3}{*}{1} & Regression & 19.426 & 1 & 19.426 & & \multirow{2}{*}{50.961} \\
\cline { 2 - 6 } & Residual & 47.949 & 148 & 0.324 & \multirow{2}{*}{$5900^{\text {b }}$} \\
\cline { 2 - 6 } & Total & 67.375 & 149 & -- & & \\
\hline
\end{tabular}

a. Dependent variable: Profit

b. Predictors: (Constant), Word of mouth

Table 11: ANOVAa

\section{References}

1. Chahal H, Bala M (2012) Significant components of service brand equity in healthcare sector. Int J Health Care Qual Assur 25: 343-362.

2. Ismail AR, Spinelli G (2012) Effects of brand love, personality and image on word of mouth, The case of fashion brands among young consumers. J Fash Market 16: 386-398.

3. Pinar M, Trapp P, Girard T, Boyt TE (2011) Utilizing the brand ecosystem framework in designing branding strategies for higher education. Int Educ 25: 724-739.

4. Lee HM, Lee CC, Wu CC (2011) Brand image strategy affects brand equity after M\&A. Eur J Market 45: 1091-1111.

5. Moradi H, Zarei A (2012) Creating consumer-based brand equity for young Iranian consumers via country of origin sub-components effects. Asia PA J Market Logist 24: 394-413.

6. Arslan FM, Altuna OK (2010) The effect of brand extensions on product brand image. J Prod Brand Manage 19: 170-180.

7. Sajuyigbe AS, Ayanleke SO, Olasunkanmi SO (2013) Impact of packaging on organizational sales turnover: A case study of patterzon zoconist cussons ( $p z)$ plc, Nigeria. Interdi J Contemp Res Bus 4: 497-508.

8. Chaneta I (2012) Marketing: Packaging and branding. J Comp Res 8: 97.

9. Ratnatunga L, Ewing MT (2009) An ex-ante approach to brand capability valuation. J Bus Res 62: 323-331.

10. Gupta S, Melewar TC, Bourlakis M (2010) Transfer of brand knowledge in business-to- business markets: A qualitative study. J Bus Ind Market. 25: 395-403.

11. Bughin J, Doogan J, Vetvik OJ (2010) A new way to measure word-of- mouth marketing. Mackisney \& Company, NY, USA.

12. Kumar V, Petersen JA, Leone RP (2010) Driving profitability by encouraging customer referrals: Who, When, and how. J Market 74: 1-17.

13. Champoux V, Durgee J, McGlynn L (2012) Corporate Facebook pages: When "fans" attack. J Bus Strat 33: 22-30. 